\title{
Testing Structural Explanations for U.S. Military Intervention: Do Support for the President and Conservatives in Congress Embolden the President?
}

\author{
Afrimadona $^{1}$, Scot Schraufnagel ${ }^{2}$ \\ ${ }^{1}$ Universitas Pembangunan Nasional "Veteran” Jakarta, Jakarta, Indonesia \\ ${ }^{2}$ Northern Illinois University, DeKalb, IL, USA \\ Email: afrimadona@upnvj.ac.id, sschrauf@niu.edu
}

How to cite this paper: Afrimadona, \& Schraufnagel, S. (2019). Testing Structural Explanations for U.S. Military Intervention: Do Support for the President and Conservatives in Congress Embolden the President? Open Journal of Political Science, 9, 253-275.

https://doi.org/10.4236/ojps.2019.92014

Received: January 7, 2019

Accepted: February 12, 2019

Published: February 15, 2019

Copyright $\odot 2019$ by author(s) and Scientific Research Publishing Inc. This work is licensed under the Creative Commons Attribution International License (CC BY 4.0).

http://creativecommons.org/licenses/by/4.0/

\begin{abstract}
In this research, we use insights drawn from Institutional Theory to explore and test the ability of Congress to check presidential foreign policy decision-making. Specifically, we test structural explanations, which tap aggregate presidential support in Congress and legislator ideology. Our concern is whether these institutional dynamics associate with a president's decision to conduct military operations. We analyze relationships in each chamber of Congress, independently, to test whether support or ideology is more or less significant in one chamber versus the other. We find, in the time period 1954 to 2013, a statistically and substantively important relationship between both presidential support in Congress and aggregate legislator ideology and the use of force decision. Moreover, this is the case in both chambers. In the testing, we control for the partisanship of the president, the political party which holds a majority of seats in each chamber, and a host of other considerations scholars argue will influence the likelihood of a show of force.
\end{abstract}

\section{Keywords}

Foreign Policy Crisis, Checks and Balances, US Foreign Policy, War Powers

\section{Introduction}

This research uses the insights of Institutional Theory to test whether legislative support for the president and chamber conservativism, in the United States, associate with a president's decision to exercise war powers or commit troops during a foreign policy crisis. Our broadest concern is to learn whether in- 
ter-institutional dynamics matter when the chief executive makes important foreign policy decisions. At least since Aaron Wildavsky (1966) proffered a "two presidencies" thesis, scholars in the US have concerned themselves with the question of inter-branch checks and balances in the exercise of foreign policy. Often findings have varied (Fleisher, Bond, Krutz, \& Hanna, 2000; Schraufnagel \& Shellman, 2001) and the broadest conclusion drawn is that the legislature's influence on presidential foreign policy decision-making is conditional. This research attempts to advance a more complete and distinctive understanding of these conditions.

As noted, our testing ground will be foreign policy crises. According to Brecher and Wilkenfeld (2000: p. 3), a foreign policy crisis exists when three conditions change the environment in which a nation-state operates. The conditions are "[1] a threat to one or more basic values... [2] an awareness of finite time for response to the value threat, and [3] a heightened probability of involvement in military hostilities." We use this definition and the coding provided as part of the International Crises Behavior (ICB) project, sponsored by Duke University and the University of Southern California, to establish our cases for analysis. Importantly, each crisis creates an opportunity for the president to use military force, yet in many instances presidents do not respond in this fashion. We wish to learn whether congressional dynamics (i.e. aggregate legislator support and ideology) associate in a predictable manner with these decisions.

To illustrate the puzzle, we consider the Ogaden Crisis in the late 1970s, involving Somalia and Ethiopia in East Africa. The conflict had real Cold War implications and Democratic President Jimmy Carter indicated he was seriously considering military action. Yet, he failed to commit troops. Twenty years later, in 1998, Democratic President Bill Clinton ordered troops to Kosovo during the country's Civil War, even though his presidential campaign two years earlier stressed the desire to keep the US out of foreign conflicts. What this research will attempt to determine is whether congressional support for the president and aggregate legislator ideology, on average, influenced these decisions.

The importance of our research question should not be left unstated. The use of military force is costly. When military intervention becomes protracted, the costs can be staggering for all involved. The fact that presidents sometimes commit militarily, but not at other times, begs thorough scholarly attention. Moreover, democratic theorists readily recognize inter-institutional competition, in the form of checks and balances, as a key ingredient of good governance (Dahl, 1971; Powell, 1982). Hence any investigation which seeks to better understand executive-legislative relations in a critical policy arena, such as the use of force, seems warranted.

\section{Institutional Theory and Policy-Making}

W. Richard Scott (2008) has been an important advocate of Institutional Theory as a useful platform to launch social science inquiry. He notes, institutions often 
control and constrain individuals and distinguish acceptable from unacceptable behaviors. Furthermore, Scott notes, it is "important to recognize that institutions... support and empower activities and actors" (Scott, 2014: p. 58). Institutions, according to Scott, provide the stimulus and subsequent guidance for social interactions. Although this framework had traditionally been the purview of sociologists, there have been adherents in political science for some time (Linder \& Peters, 1990; Ingberman \& Villani, 1993) as well as contemporary scholarship, which uses this theoretical frame (Lektzian \& Souva, 2007; Rothstein \& Stolle, 2008). Much of the work in political science, which relies on the insights of Institutional Theory, has been centered on better understanding the policy-making process.

An important insight of Institutional Theory is a recognition that imitation is an essential element of policy decision-making. Specifically, organizations look to peer institutions for signals as to appropriate behavior and act accordingly. In the US we see "institutional imitation" in the form of policy diffusion from one state to another. In our context, the legislature and the executive can be seen as the relevant peer institutions. In short, we expect that when one of the legislative chambers in Congress is more supportive of the president this "imitation" will embolden the president. Institutional theorists also recognize that institutions often compete and that when they are competing for political power a central question is the extent to which a dominant institution yields to a subordinate institution (Gerring, Ziblatt, Van Gorp, \& Arévalo, 2011). In our research, focused on US foreign policy-making, we might consider the executive the dominant institution, at least in the modern era, and wish to learn more about the extent to which the chief executive will cede power to the legislature or consider congressional preference.

It is important to note that Institutional Theory does not compete directly with Rational Choice as a means for understanding policy-making. The latter suggests policy-making is a process punctuated by decision-making points that involve individual actors. Institutional Theory accepts this premise but would add that institutional forms, such as majority party control of government and separate branches of government sharing power, will have explanatory power in their own right. The institutional arrangements, in effect, define the conditions under which individual actors consider their rational decision-making calculi. In our instance, we hold decision-making deliberations in the White House may be altered by the institutional support the administration receives, or does not receive, from Congress.

To date, there has been a great deal of work which tries to understand the inter-branch institutional dynamics that produce military action. ${ }^{1}$ Much of this work implicitly utilizes insights extended by Institutional Theory. We believe this research, which explicitly recognizes that the attitudes, beliefs, and values of 
political actors are shaped by inter-institutional imitation and competition will further enhance our grasp of the dynamics of US military intervention. Today, many remain pessimistic about Congress's ability to restrain the executive in the areas of war powers, specifically, and foreign policy more generally (Fisher, 2004; Irons, 2005). Others, however, counter that presidents will, at least sometimes, base foreign policy decisions on the anticipated reaction they will receive from the legislature (Lindsay \& Ripley, 1993). ${ }^{2}$ We intend to shed additional light on this debate.

\section{Constraining Presidents during a Foreign Policy Crisis}

Some international relations scholars recognize the primary limitation or constraint on a political leader's foreign policy choices is the distribution of power among nations (Mastanduno, 1997; Mearsheimer, 2001; Waltz, 1979). Others, from a constructivist perspective, perceive that change in the international structure of ideas shapes what leaders can do in foreign policy (Finnemore \& Sikkink, 1998; Ruggie, 1998; Tannenwald, 1999; Wendt, 1992). But, others recognize an important role for domestic actors and see both interest groups and the legislature constraining a president's foreign policy decision-making (Christenson \& Kriner, 2017; Fordham, 1998; Howell \& Pevehouse, 2005, 2007a, 2007b; Kriner, 2006; 2010; Lindsay, 1994; Milner \& Tingley, 2015; Narizny, 2001). Still others, studying foreign policy-making, recognize the centrality of the president and the executive-branch agencies (Cooper, 2014; Deering \& Maltzman, 1999; Fisher, 2004; Howell \& Lewis, 2002; Krause \& Cohen, 1997, 2000; Marshall \& Pacelle, 2005; Mayer, 1999, 2002; Moe \& Howell, 1999a, 1999b).

With Institutional Theory as our backdrop, we hold that Congress ought to be able to constrain the executive in the United States via formal procedural mechanisms found in the US Constitution. Indeed, the Constitution establishes Congress as a dominant player in foreign policy. As one legal scholar notes, "the Constitution expressly divided foreign affairs powers among the three branches of government, with Congress, not the president, being granted the dominant role" (Koh, 1991: p. 75 emphasis in original). This is most important when the United States considers hostilities against other nations, as the Constitution assigns Congress the power to "declare war" (Weissman, 2017: p. 133). ${ }^{3}$ Certainly, much practice conformed to these constitutional expectations in the early years of the Republic.

Yet, presidential dominance in war powers began to surface at the turn of the

${ }^{2}$ Scholars show that presidential approval ratings tend to increase when Congress supports presidential decisions. In contrast, when critical voices predominate in Congress, public support for the president diminishs. For instance, congressional support can affect the "rally around the flag" effect that often occurs when troops are deployed (Mueller, 1973; Brody, 1991; Lian \& Oneal, 1993). ${ }^{3}$ Howell and Pevehouse (2007a) claim, there are at least two ways in which Congress can affect a president's foreign policy. First, is through the constitutional role play by Congress as the chief appropriations agent; but also, through the ability of Congress to stoke public dissent (see also Christenson \& Kriner, 2017). When a president launches foreign policy action such as troop deployments, members of Congress have often engaged in public debates, raising concern about the costs involved and expressing doubt about the president's plans (Berinsky, 2007; Zaller, 1992). 
twentieth century when, for instance, the executive unilaterally sent troops to China, Central America, and the Caribbean in the name of American national interests. However, Congress still played an important role during this time period as evidenced by the statutory decision to enter World War I, the passage of neutrality legislation in the 1930s, and the support of military aid to the United Kingdom under the Lend-Lease program at the onset of World War II (Weissman, 2017: p. 133). It was not until the Cold War that Congress began to yield more completely foreign policy authority to the president. ${ }^{4}$

To be clearer, research about congressional influence on presidential foreign policy decisions clusters roughly into two camps. One group sees Congress as a particularly relevant constraint (Christenson \& Kriner, 2017; Howell \& Pevehouse, 2005, 2007a, 2007b; Kriner, 2006, 2010; McCormick \& Wittkopf, 1990). For example, Howell and Pevehouse (2005, 2007a), consistent with insights drawn from Institutional Theory, show that the partisan composition of Congress can affect the president's decision to use military force. Specifically, they find that when the opposition party controls Congress, the president is less likely to order military action. Moreover, they note that Congress, through legislation, appropriations, hearings, and public appeals, can increase the cost of military adventures and discourage a president from committing troops (Howell \& $\mathrm{Pe}$ vehouse, 2007a).

By contrast, another group suggests that congressional influence is limited. Perhaps the most famous collection of research representing this view is the two-presidencies thesis that Wildavsky (1966) first proffered. His contention was that Congress is not as active and plays only a subsidiary role in foreign policy. Consistent with Wildavsky's proposition, Cohen (1991) finds that presidents are more able to control the agenda in foreign policy than in other issues areas. Canes-Wrone, Howell, and Lewis (2008: pp. 4-5) find presidents in the modern era more knowledgable about foreign policy affairs-ranging from the relevant international players, to the status of negotiations, and to covert operations-than Congress. Others, using direct tests of the two-presidency thesis argue that congressional support for the president on key foreign policy roll calls tends to diminish over time (Sigelman, 1979). And, Fleisher et al. (2000) observe that the absolute level of support for minority party presidents' foreign and defense policy positions has declined since Ronald Reagan's second term. ${ }^{5}$ Debates within the literature aside, we move forward to provide our own models of presidential decision-making to test congressional influence anew.

\footnotetext{
${ }^{4}$ Mounting casualties during the Vietnam War arguably convinces legislators that presidential foreign policy power needed to be checked anew, and the War Powers Act was passed in 1973 over President Richard Nixon's veto. Although the Act was seen as evidence of congressional assertiveness in foreign policy, most scholars agree that it fails to achieve its intended purpose. Moreover, every president since Nixon, regardless of political party, has refused to recognize the legislation's constitutionality and Congress has been reluctant to challenge this defiance (Kartzmann, 1990: p. 35). This leads one scholar to call the Act a "monument to legislative futility" (Irons, 2005: p. 7) and another "a sellout, a surrender" (Fisher, 2004: p. 65).

${ }^{5}$ See also Schraufnagel and Shellman (2001), who find that the willingness of Congress to defer to the president in foreign policy is conditioned by who is serving in the Oval Office.
} 


\section{Modeling US Military Involvement in a Foreign Policy Crisis}

We offer two primary hypotheses regarding the ability of the legislature to influence a president's decision to commit the US military during a foreign policy crisis: 1) the president is more likely to intervene militarily when he has stronger levels of political support in the House and Senate, and 2) the more conservative the two chambers of Congress, the more likely the president will intervene militarily in a foreign policy crisis. Not unlike "public mood," which is found to influence government action in the domestic arena (Stimson, 1999), we suspect the mood of Congress, as defined by presidential support and the aggregate ideological leaning of members, can influence a president's foreign policy decisions.

Importantly, our two key explanatory variables relate to partisanship and we will capture presidential support using party-centric variables; but in their essence both our measure of presidential support and our indicator of conservativism transcend political party. Our approach, in many ways, is consistent with the notion of pivotal politics, which embraces the role of the pivotal legislator, the one who produces the super-majority support needed to close debate in the US Senate or to override a presidential veto (Krehbiel, 1998). Notably, the pivotal legislator may or may not be among the president's co-partisans. Theoretically, we hold that when the pivotal legislator in Congress supports the president, this institutional dynamic will influence decision-making and afford the chief executive an opportunity to choose military action during a foreign policy crisis.

\subsection{Establishing Cases for Analysis}

As noted, we rely on the work of the International Crises Behavior (ICB) project to define a foreign policy crisis (Brecher, 2008). Although some scholars treat foreign policy crises and international crises similarly (Hermann, 1972; Lebow, 1981), Brecher who has been a lead scholar in the collection and dissemination of ICB data, clearly distinguishes the two (Brecher \& Wilkenfield, 2000; Brecher, 2008). The key distinction is the source of the crisis. A foreign policy crisis can erupt when belligerent nations face-off, but also from the internal environment of a state when there are external ramifications (e.g., the internal Austrian crisis, triggered by the assassination of Chancellor Dollfuss by Austrian Nazis in 1934, led to external escalations). An international crisis, in contrast, only arises when there are disruptive interactions between states. We are interested in the more inclusive set of crises.

In this work, we use the ICB actor-level dataset (Version 11), where each country every quarter (or three months) is the unit of analysis. But we also report an auxiliary analysis in the Appendix which uses each crisis as the unit of analysis. The ICB dataset contains information for all crises occurring during the time period 1918-2013. Because of the potential for bias created by comparing dissimilar time periods, and because our normative concerns are the current state of affairs, we limit the statistical testing to the era bookended by the Cold War and the beginning of the second Barack Obama Administration (1954-2013). 
The data set contains 80 variables divided into three groups: crisis dimensions (42 variables), contextual variables (14 variables) and actor attributes (24 variables). Because the phenomenon of interest is US military intervention, we exclude observations where the US is one of the primary crisis actors. We are less interested in how the US handles her own crises and more interested in the conditions under which the US gets involved in a crisis occurring elsewhere in the world. ${ }^{6}$

\subsection{Model Specifics}

The dependent variable in our models is dichotomous and measures whether the US gets involved militarily in a foreign policy crisis. The value of "1" indicates direct US military intervention, while the value of " 0 " is non-intervention. ${ }^{7} \mathrm{We}$ have complete data on 458 cases, during the time period studied, and the US was engaged in direct military involvement in 53 of these cases or 11.6 percent of the time.

To capture our two primary explanatory variables, representing congressional dynamics, we use factor analysis to provide more robust indicators of legislator support and ideology. Specifically, our factor analysis includes six different items and we look for latent factors and the scores associated with them to use in our modeling. Three items we believe will capture aggregate legislator support and the other three are intended to capture legislator conservativism. Considering Support for the President, each of the items is either directly or indirectly related to the number of co-partisans a president has in each chamber. First, we use the percentage of members from the president's party in each chamber. ${ }^{8}$ Second, we follow Howell and Pevehouse (2007a) and use what is called the president's "party power," calculated as follows: (the percent in president's party ${ }^{\star}$ party_unity_vote support $[t-1])$ - (the percent in opposition party * opposition party_unity_vote support $[t-1]) .^{9}$ Because the party power consideration produces a Congress specific value, and the military intervention occurs sometime during a Congress, we use the previous Congresses' party power score in the factor analysis to avoid a simultaneity problem when we run the regression

${ }^{6}$ Relevantly, the International Crisis Behavior project finds that among the great powers, the US is the most frequent third-party intervener in any type of crisis. This is true even when compared to the Soviet Union its superpower rival during the Cold War years.

${ }^{7}$ This variable is recoded from the ICB variable of USINV (US INTERVENTION). The original scale of the intervention variable ranges from 1 to 9; however, we collapse the values of 1-7 (non-involvement, neutrality, political involvement, economic involvement, propaganda involvement, covert involvement, and semi-military involvement) into the value of " 0 " indicating non-military intervention. We recode the value of 8 (direct military intervention) into the value of " 1 " denoting US direct military intervention. We drop the observations with a value of 9 which represent cases when the US is a crisis actor.

${ }^{8}$ The data on party composition in Congress are obtained from Brookings Vital Statistics on Congress compiled by Ornstein et al. (2017).

9“Cohesion" is determined by each party's level of support for the party's majority position on party unity votes. Party unity votes are defined as a roll call when a majority of one party votes in opposition to a majority of the other party. Data on Party Unity Votes are originally published by Congressional Quarterly Weekly Reports and compiled by Ornstein et al. (2017) and published in Brookings Vital Statistics on Congress. 
models. This second consideration provides additional weight to the number of the president's co-partisans in Congress; but also considers the extent to which these individuals and their partisan opponents are cohesive in their voting behavior. Third, we use presidential 'batting averages' in each Congress preceding the foreign policy crisis. Batting averages are measured by dividing the number of successful or winning congressional roll call votes which support the president's stated position by the total number of roll call votes on which the president had taken a clear position. ${ }^{10}$

We also use three items in our attempt to tap each chamber's level of Conservativism. As with the congressional support score, we look for a possible latent variable in the factor analysis in order to combine related considerations into a single variable that is a more complete indictor of our concept. The first item, in this instance, is a measure of the median DW-NOMINATE score for each chamber. The consideration, arguably, measures how conservative the chamber is during each Congress studied. ${ }^{11}$ The second item is an indicator of the ideological predisposition of the standing committees in each chamber. We use the mean DW-Nominate score for all committees or the average of each committee's average value. Given that standing committees are made up of caucus and conference members, this is necessarily very closely correlated to the chamber scores $(r=.83$ for the House and $r=.97$ for the Senate). However, theoretically and empirically, a committee average score is not the same as a chamber average. Because some committees are skewed, and decidedly over-populated by majority party members, this consideration gives additional deference to the ideological position of the majority party. The third consideration is the average DW-NOMINATE score of members on the Senate Foreign Relations and the House Foreign Affairs standing committees. The ideologies of these committees, which deal directly in foreign policy matters on a routine basis, might be especially relevant and should be part of our measure of Conservativism. Each measure of chamber ideology is standardized before conducting the factor analysis.

The factor analysis of the six items considers joint variation in response to unobserved latent variables. As hoped, the analysis uncovers two distinct dimensions or factor loadings that correspond precisely with our expectations. The three presidential support considerations all load on the second dimension and the loadings are always high ranging from .75 to .98 for the House and .81 to .96 for the Senate. Considering the first factor, our three considerations of ideology all load on a single dimension with factor loadings that are even higher; always

\footnotetext{
${ }^{10}$ Data are obtained from Ornstein et al. (2017) in Brookings Vital Statistics on Congress.

${ }^{11} \mathrm{~W}$-NOMINATE scores are calculated for each Congress independently and a chamber median score in one Congress is not necessarily comparable to the median score in a subsequent Congress. However, the dynamic weighting process used to develop DW-NOMINATE scores makes use of "bridge members" who have served in multiple Congresses to compare the positions of legislators who have never served together. The ideological scores we use are based on the DW-NOMINATE scores developed by political scientists Keith Poole and Howard Rosenthal (available at https://www.voteview.com/). A positive score denotes a conservative ideology, while a negative score denotes a liberal one. The precise DW-NOMINATE values we use are compiled by Ornstein et al. (2017) and published in the Brookings Vital Statistics on Congress.
} 
above .86 and often above .95 . We use the two factor scores derived from this analysis as our predictor variables in the regression models. Because larger scores, in both instances, suggest more support or greater conservativism we anticipate positive coefficients from these tests (consistent with our hypotheses). The Appendix reports additional detail about the factor analyses and the results of diagnostic tests, which suggest our scores are internally consistent.

To control for the possibility of a spurious relationship between the dependent variable and our key explanatory variables, we include in the models a series of contextual considerations and conflict specific control variables. Each of the variables has been mentioned in previous scholarship, which attempts to elucidate presidential use of force decision-making.

\subsection{Contextual Control Variables}

First, some studies show presidents are more likely to engage in force when the domestic economy is in trouble (Fordham, 1998; James \& Oneal, 1991). To account for this possibility, we include a quarterly Misery Index score, which adds the country's unemployment and inflation rates. ${ }^{12}$ To avoid the possibility of a simultaneous relationship between the Misery Index and the decision to engage in military intervention, we use a one-quarter lag of the index in the modeling. In other words, the Misery Index for the US in the quarter year before the foreign policy crisis occurs becomes our predictor. We anticipate a positive association.

The second contextual variable, relates to the diversionary use of force thesis. Scholars argue a presidential decision to engage in military intervention is associated with the president's popular support. As Ostrom and Job (1986) find, presidents are more likely to command the use of force abroad when their popularity is declining. To account for this we include the average Presidential Approval rating in the quarter year prior to the foreign policy crisis and anticipate a negative relationship. ${ }^{13}$ Third, we include a binary variable to tap majority party control of each chamber. The party in power will almost certainly be highly correlated with our key ideology indicator, and failure to control for party might subject our models to omitted variable bias. ${ }^{14}$ Thus, we include a variable scored

${ }^{12}$ The data on unemployment and inflation are obtained from the US Bureau of Labor Statistics. While data on unemployment are straightforward, the data on inflation needs to be calculated based on the annual Consumer Price Index (CPI) as regularly published by US Bureau of Labor Statistics. Because CPI is "a measure of the average change over time in the prices paid by urban consumers for a market basket of consumer goods and services" and inflation is "the overall general upward price movement of goods and services in an economy" (Bureau of Labor Statistics, 2013), we calculate inflation as follows: INFLATION $_{t}=\frac{c p i_{t}-c p i_{t-1}}{c p i_{t-1}} * 100$.

${ }^{13}$ The data are obtained from the Presidential Job Approval database of the American Presidency Project hosted by the University of California, Santa Barbara (Peters \& Woolley, 2018).

${ }^{14} \mathrm{~A}$ sensitivity analysis confirms omitted variable bias. Because Democratic-controlled Congresses have a negative and statistically significant relation with the latent ideology variable in both chambers, and the Democratic-controlled Congress variable and the latent variables of House and Senate ideology have different impacts (in direction) on the decision to intervene militarily (the former has a positive association while the latter has a negative one) omitting the Democratic-controlled Congress variable will overestimate the influence of ideology on the decision to use military force and cause Type I error, a false-positive (see Wooldridge, 2013: pp. 87-92). 
"1" if there is a Democratic Party Majority in the chamber and the value of " 0 " if there is a Republican majority. A priori we do not have a specific prediction regarding the direction of the association, especially given that we are including the ideology measure (Conservativism).

The fourth contextual control variable is the Presidential Election Cycle. Again, the presidential use of force literature suggests presidents are more likely to engage in force abroad during the months preceding an election. As diversionary use of force theory suggests, the presidential election provides incentive for the president to engage in military adventure abroad "in order to appear strong to the voting public and thereby enhance their own or their successors' chances for election" (Meernik, 2000: p. 554; James \& Oneal, 1991; Ostrom \& Job, 1986). The election cycle dummy variable is scored " 1 " for the three quarters preceding a presidential election, or the first three quarters of each presidential election year and a positive coefficient is anticipated.

A fifth contextual consideration is the president's party. This variable tests whether a Republican President, possibly more conservative in the time period of this study, is more likely to engage in military intervention during a foreign policy crisis. As some studies show, in the post-WWII era Republican presidents have been more "hawkish" than Democrats (Busby \& Monten, 2012; Gries, 2014; Holsti \& Rosenau, 1996; Rathbun, 2008; Wiarda, 2009). The variable is coded so that " 1 " indicates the chief executive is from the Republican Party and "0" if the president is a Democrat. We hypothesize a positive coefficient in the regression analyses.

Next, we include three contextual considerations that tap the effect of the international system on the likelihood of military intervention in a foreign policy crisis. The first is US Hegemonic Power and is measured using annual values of the country's "military capabilities," as reported in the Correlates of War Capabilities dataset (Small \& Singer, 1990). Scholars suggest declining states are more likely to be aggressive (Copeland, 2000). To test this thesis, we subtract the contemporaneous value from the previous year's value $\left(t_{1}-t_{0}\right)$. For instance, 2000 had a value of .1427 and 2001 had a value of .1414 and we use the value of -.0013 as a predictor of the decision to go to war in 2001. A positive number is expected to associate with a reduced likelihood of a military commitment or a negative association is expected.

We also control for World Disputes or the number of non-US militarized interstate disputes (MID) because arguably war begets war (Howell \& Pevehouse, 2005, 2007a; Meernik, 1994). It is expected there will be a positive association between the number of non-US MIDs and the likelihood of US intervention in a foreign policy crisis. ${ }^{15}$ Finally, we include a contextual dummy variable for the period of the Cold War to capture the systemic effect of a superpower rivalry, which arguably spawned interstate conflicts during the time period studied (Howell \& Pevehouse, 2007a) and a positive coefficient is expected.

${ }^{15}$ The data on non-US MIDs are obtained from Correlates of War Project Militarized Interstate Disputes Dataset (Palmer et al., 2015). 


\subsection{Conflict Specific Controls}

To provide the most rigorous test of our thesis it is necessary to also account for specific considerations related to each foreign policy crisis. Expressly, we control for five different considerations: a Violent Trigger, the Power Disparity between the countries involved, ${ }^{16}$ Geostrategic Salience, a US Ally, and last, a Non-Democratic Actor. Each of the five considerations is expected to influence the foreign policy decision-making of US presidents (Brecher \& Wilkenfeld, 2000; Brecher, 2008; Butler, 2003; Prins, 1999). The first two (conflict specific) variables capture "just war" arguments (Butler, 2003), which hold the US is more likely to intervene in an international crisis when there is a well-grounded reason for intervention. To measure the violent trigger consideration, we use the ICB data and score cases " 1 " if it is suggested that the crisis was triggered by a direct violent act such as invasion of air space, the bombing of a large target, or a large-scale military attack. If this does not occur the case is scored "0." Next, we measure power disparity, with an interval-level measure found in the ICB dataset, which captures the demographic/geographic/and military assets of crisis actors. We difference these values to establish "power disparity." With the two 'just war' considerations, we hypothesize positive associations.

The other three conflict specific considerations represent so-called "crisis saliency" hypotheses. To Prins (1999), when East-West relations are involved there is greater strategic, or geostrategic salience, which may lead the US to get involved militarily. We measure this consideration, again, using the ICB database, which designates five categories of geostrategic salience. We collapse the five categories into a single dichotomous indicator. Categories 3-5, which indicate the crisis affects the global system and/or East-West relations and at least one regional sub-system, such as Western Europe, the Americas, or East Asia, are scored "1". The first two categories, which indicate the crisis does not influence East/West relations are scored "0."17 Next, when a US ally, defined as a nation-state with a defense pact with the US is a crisis actor, we score the case "1" and anticipate a positive association. The last variable taps the presence of non-democratic actors in the foreign policy crisis and cases are scored "1" if one or both of the actors involved has regime characteristics of civil authoritarianism, military-indirect rule, military-direct rule, or military dual authority as defined in the ICB data set. Overall, we hold the US is more likely to get involved when any of the three crisis saliency considerations is present.

Finally, to account for unobserved factors related to each of the presidents, we include a Presidential Fixed Effects term. This fixed effect idiom controls for much of the unexplained variation that is specific to the president such as their personality traits, ideology, and so forth. Because our dependent variable is binary,

\footnotetext{
${ }^{16}$ Both state and non-state actors are included.

${ }^{17} \mathrm{We}$ also try creating four different binary variables leaving out Category One (only one subsystem is affected while the East-West relations are not impacted at all). This alternative model specification does not in any way influence the relationship between our key explanatory variables and the dependent variable. We opt for the single binary consideration for the sake of parsimony.
} 
we employ a Probit Regression model estimated using Maximum Likelihood. We cluster the standard errors by Congress because we have repeated measures of Congress-level variables as predictors. Because it is likely that each decision to intervene in a foreign policy crisis, within a particular Congress, is related to one another a failure to cluster the standard errors will render the hypothesis testing unreliable because we would be overestimating the precision of our estimates.

\section{Results}

Table 1 reports the results of the regression analyses. The coefficients derived from Probit models do not provide any substantive meaning unless converted

Table 1. US military intervention (1954-2013): The role of legislator support for the president and legislative conservativism.

\begin{tabular}{|c|c|c|c|}
\hline & Exp. & House Model & Senate Model \\
\hline Key Explanatory Variables & Sign & Coefficient (s.e.) & Coefficient (s.e.) \\
\hline Support for the President (House) & + & $1.338(.366)^{* *}$ & \\
\hline Support for the President (Senate) & + & & $1.357(.362)^{\star *}$ \\
\hline Conservativism (House) & + & $2.395(.727)^{\star \star}$ & \\
\hline Conservativism (Senate) & + & & $1.395(.396)^{\star *}$ \\
\hline \multicolumn{4}{|l|}{ Contextual Controls } \\
\hline Misery Index [t - 1] & + & $.018(.067)$ & $.003(.093)$ \\
\hline Presidential Approval $[\mathrm{t}-1]$ & - & $.040(.018)^{\star}$ & $.039(.020)$ \\
\hline Democrat Party Majority & Null & $1.020(.892)$ & $-.303(.777)$ \\
\hline Presidential Election Cycle & + & $.883(.446)^{\star}$ & $.364(.490)$ \\
\hline Republican President & + & $-1.513(.779)$ & $-1.221(.675)$ \\
\hline US Hegemonic Power & - & $-10.312(34.196)$ & $-19.224(21.833)$ \\
\hline World Disputes & + & $.042(.012)^{\star \star}$ & $.063(.019)^{\star *}$ \\
\hline Cold War & + & $-.330(.763)$ & $-.773(.706)$ \\
\hline \multicolumn{4}{|l|}{ Conflict Specific Controls } \\
\hline Violent Trigger & + & $-.327(.337)$ & $-.407(.327)$ \\
\hline Power Disparity & + & $.004(.003)$ & $.003(.003)$ \\
\hline Geostrategic Salience & + & $2.148(.473)^{\star *}$ & $2.112(.466)^{* *}$ \\
\hline US Ally & + & $-.152(.481)$ & $-.161(.452)$ \\
\hline Non-Democratic Actor & + & $.404(.443)$ & $.339(.423)$ \\
\hline Constant & & $-8.068(1.734)^{\star *}$ & $-8.037(1.828)^{\star *}$ \\
\hline Presidential Fixed Effects & & Yes & Yes \\
\hline McFadden Pseudo $\mathrm{R}^{2}$ & & .56 & .56 \\
\hline Deviance & & 143.9 & 143.6 \\
\hline AIC & & 187.9 & 187.6 \\
\hline $\mathrm{BIC}$ & & 278.7 & 278.4 \\
\hline $\mathrm{n}$ & & 458 & 458 \\
\hline
\end{tabular}

${ }^{*} p<.05 ;{ }^{* *} p<.01$ (two-tailed test). Robust standard errors clustered by congress. 
back to predicted probabilities. However, we can still learn something about the statistical significance of the many predictor variables displayed in the table. Straightaway, we note that congressional Support for the President in both chambers is statistically linked to US military involvement in a foreign policy crisis, on average, all else being equal. The test of Conservativism produces an equally strong statistical link in each chamber and we can now argue that the more conservative each chamber's ideological makeup, the more likely the US president is to commit troops during a foreign policy crisis.

Interestingly, once we account for support for the president and ideology many of the contextual considerations are not statistically linked to military action. Only the number of World Disputes is related to military intervention in both chamber-specific models. Presidential Approval and the Presidential Election Cycle are also predictors in the House model. The stronger legislator/constituent relationship in the House might be what causes these additional contextual considerations to have some explanatory power in the analysis which considers the Lower Chamber. When considering the conflict specific control variables, Geostrategic Salience or the involvement of East-West tensions in the crisis is the only statistically significant predictor in our analyses.

Considering the substantive significance of our two key explanatory variables it is important to note that the factor scores we use to capture these considerations are standardized measures, with mean scores equal to "0" and a standard deviation is equal to " 1. " In the Senate, we learn, a one standard deviation increase in the measure of congressional support for the president increases the predicted probability that the president conducts military intervention in a foreign policy crisis, on average, by more than 17 percent (.177). It is important to note that this is an average increase, because the increase in the predicted probabilities is not linear. At lower levels of support the effect is not as great as it is when legislator support is higher. In the House, a one standard deviation increase leads to greater than a 18 percent (.186) increase in the probability of the president committing troops. Again, the probabilities are not linear. Considering the ideology measure, in the Senate, a one standard deviation increase in the measure of conservativism increases the probability of the president deciding in favor of military intervention in a foreign policy crisis by .193 or a little less than a 20 percent increase. In the House, a one standard deviation increase in conservativism increases the predicted probability of the president engaging in military intervention in a foreign crisis by .322 or an increase of more than 32 percent.

Figure 1(a) and Figure 1(b) provide a visualization of the effects Support for the President and Conservativism have on military interventions. Note, all lines represent statistically significant relationships and the steepness of the lines suggest our two explanatory variables are each strongly linked to the dependent variable. When the factor score, representing presidential support (Figure 1(a)), is average or " 0 " in either chamber the probability of military action is about .18 suggesting an 18 percent chance the president will commit troops. The two 


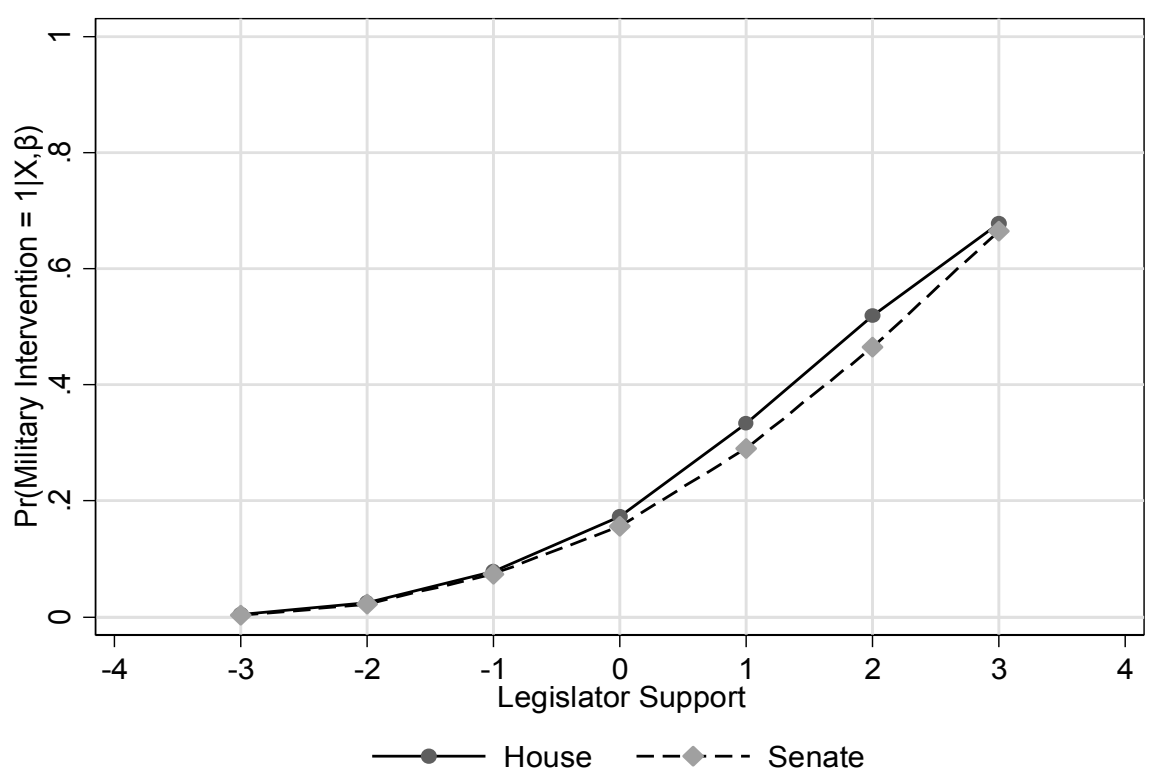

(a)

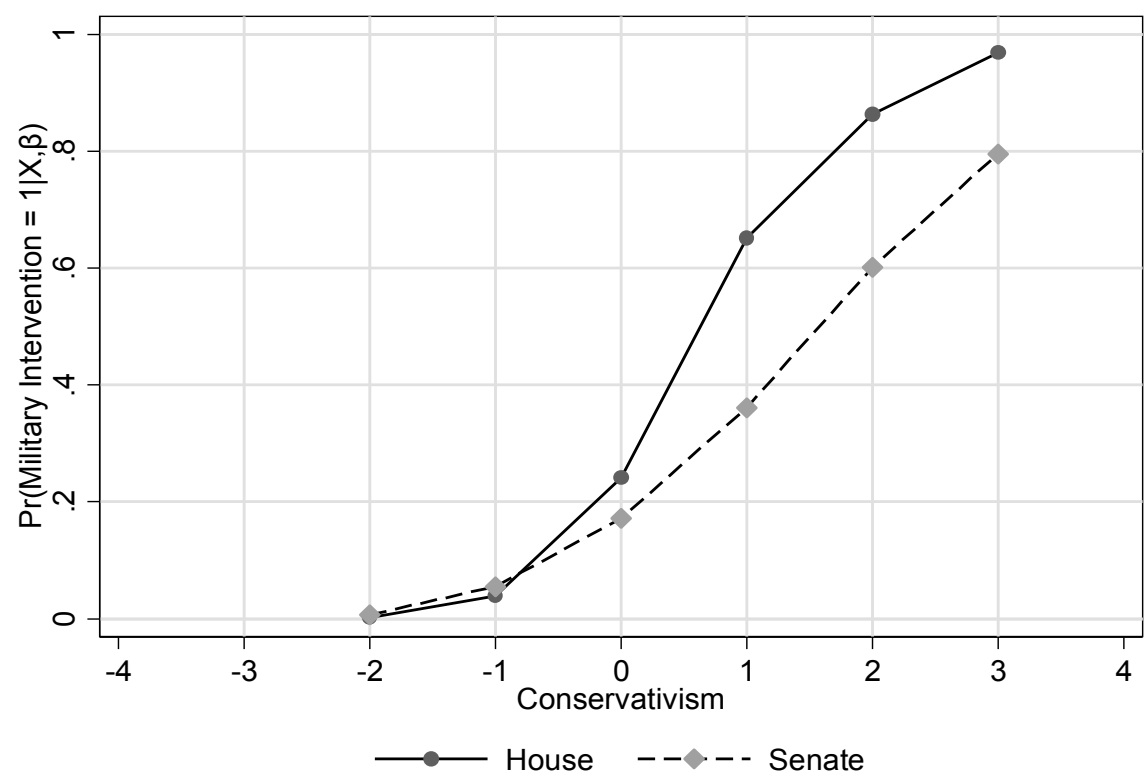

(b)

Figure 1. (a) Predicted probability of military intervention under different levels of legislator support; (b) Predicted probability of military intervention under different levels of conservativism.

chamber lines diverge slightly as support grows, yet one can see clearly, in Figure 1(a), that above average support for the president increases the probability of troop deployments markedly.

Considering ideology (Figure 1(b)) a factor score of -2 , representing a chamber ideology that is two standard deviations more liberal than average, suggests the probability of military intervention is next to zero. Considering a one standard deviation increase above the mean Conservativism score, the probability of military intervention increases rather dramatically. This is especially the 
case in the House model, as established by the steeper line when one moves from a Conservativism score of "0" to a score of " 1 ".

When we turn our attention to the question asked in the Introduction about the Ogaden Crisis versus the Kosovo Civil War, we can work backwards to check the construct validity of our findings. It turns out the factor scores used to capture House and Senate conservatism in the $95^{\text {th }}$ Congress (1977-78), when the East African conflict was occurring, were considerably lower than average. And, even though one presidential document mentions President Carter was willing "to aggressively challenge" the Soviet Union for influence in Somalia (Makinda, 2008: p. 368), the US did not enter the fray. One can imagine that a Congress less conservative than average is part of the explanation for inaction. On the other hand, during the Kosovo Civil War (1998), which took place in the Bill Clinton Administration, Republican majorities in both chambers, beginning in 1995 and lasting through the end of his term in 2001, meant Congress was more conservative, on average, and this crisis did result in a commitment of US military forces. ${ }^{18}$

Of course, it is possible to glean other examples to illustrate our summative findings, but our concern was testing for average association. ${ }^{19}$ We can now say with some certainty that, on average, Congress can, and does, influence presidential use of force decision-making. We examine the chambers, independently, to test whether our findings would be chamber sensitive. In other words, we wanted to make sure that presidential support and legislator ideology in one chamber was not driving our results. By looking at the chambers separately we learn that our two key explanatory variables matter across the board, or across both chambers. Moreover, they matter in models that put both Support for the President and Conservativism in the same model alongside a whole host of contextual and conflict specific considerations.

\section{Discussion}

We began this investigation with a concern to better understand the nature of inter-branch checks and balances in foreign policy-making in the United States. Most specifically, we wished to understand whether institutional support from the legislative branch and congressional ideology matter to the president when a decision is being made to deploy troops during a foreign policy crisis. We did so with a full appreciation that qualitative scrutiny of the motivations of the key decision makers involved would undoubtedly provide much relevant and rich detail

\footnotetext{
${ }^{18}$ The US military intervention was part of a broader North Atlantic Treaty Organization initiative. ${ }^{19}$ It should not be missed that our findings are produced in models that include two different congressional dynamics, which in certain time periods are correlated with one another. For instance, in periods of divided government with a Democrat in the White House, presidential support would be lower while conservativism would be higher. In periods of unified party government and a Republican in the White House the two considerations would be positively correlated. We bring this up because these correlations might otherwise inflate standard errors and make it more difficult to find statistically significant associations between our measures and the use of force decision by the US president.
} 
about each and every military intervention. In other words, we do not pretend that the "birds-eye" view reported in this manuscript is capturing all the important predictors of decision-making in individual crisis situations. Yet, our institutional approach wished to learn something more about macro-level constraint on presidential decision-making. Specifically, we wished to discover whether broader concerns, defined by congressional dynamics, help specify the parameters by which foreign policy decision-making options are defined? We now believe that the answer to this question is yes.

Most specifically, our findings regarding legislator support suggest that when the president does not have the support of Congress, the potentially costly decision to commit troops is less likely to occur. Again, this is the case after controlling for a myriad of competing explanations. The findings regarding ideology, or conservativism, are also telling. When considering the possibility of inter-institutional checks and balances, we now know that a more liberal House and Senate will provide a more robust check on the tendency of the chief executive to commit troops during a crisis. If one feared a recalcitrant and hawkish chief executive, prone to involve the US militarily, a sensible response would be to vote more liberals into Congress in the next election cycle. On the other hand, if a president seemed "weak kneed" and unwilling to stand up to human rights abuses or violent behavior by a foreign actor, a reasonable approach would be to elect more conservatives to Congress in the next election.

Notably, our work does not speak directly to the "two-presidency thesis" because we are only looking at a particular foreign policy decision and have not compared our results to a test of presidential decision-making in the domestic policy arena. This may prove to be a productive avenue for future research. We would like to point out an interesting incongruity, however. We know, anecdotally, that contemporary US presidents often issue domestic executive orders, or unilateral presidential policy proclamations, in response to their lack of support in Congress. If this is a systematic occurrence, it would suggest a very different dynamic in domestic policy-making than the one we uncover in foreign policymaking. If the lack of legislator support causes the chief executive to go it alone when making domestic policy decisions, there may indeed be something akin to "two-presidents". Considering the decision to commit troops, we learn the chief executive in the US is less likely to "go it alone" if they do not have the support of Congress. Understandably, these are not exactly two sides of the same coin, but the interplay is sufficiently intriguing to warrant further scrutiny.

In sum, Institutional Theory suggests that organizational subtleties can condition the behavior of rational actors. Moreover, institutional imitation or competition can drive policy-making, presumably, at all levels of government. Still more, this theory suggests that institutions are defined, in part, by the predispositions of the collective or the people who populate these organizations. We have not found anything in this research to contradict these claims. Instead, our research codifies that institutional support or "imitation" can influence at least one type of foreign policy-making, the decision to commit troops. We also learn that 
group ideology, in our case the ideological makeup of either the House or Senate, can also associate strongly with a president's decision to intervene militarily in a foreign policy crisis.

\section{Conflicts of Interest}

The authors declare no conflicts of interest regarding the publication of this paper.

\section{References}

Bartolomew, D. J., Steele, F., Moustaki, I., \& Galbraith, J. I. (2008). Analysis of Multivariate Social Science Data (2nd ed.). Boca Raton, FL: CRC Press.

Berinsky, A. J. (2007). Assuming the Costs of War: Events, Elites, and American Public Support for Military Conflict. Journal of Politics, 69, 975-997. https://doi.org/10.1111/j.1468-2508.2007.00602.x

Brands, H. W. (1987). Decisions on American Armed Intervention: Lebanon, Dominican Republic, and Grenada. Political Science Quarterly, 102, 607-624. https://doi.org/10.2307/2151304

Brecher, M. (2008). International Political Earthquakes. Ann Arbor, MI: University of Michigan Press. https://doi.org/10.3998/mpub.293883

Brecher, M., \& Wilkenfeld, J. (2000). A Study of Crisis. Ann Arbor, MI: University of Michigan Press.

Brody, R. A. (1991). Assessing the President: The Media, Elite Opinion, and Public Support. Palo Alto, CA: Stanford University Press.

Bureau of Labor Statistics (2013). Overview of BLS Statistics on Inflation and Prices. https://www.bls.gov

Busby, J. W., \& Monten, J. (2012). Republican Elites and Foreign Policy Attitudes. Political Science Quarterly, 127, 105-142. https://doi.org/10.1002/j.1538-165X.2012.tb00722.x

Butler, M. J. (2003). U.S. Military Intervention in Crisis, 1945-1994: An Empirical Inquiry of Just War Theory. Journal of Conflict Resolution, 47, 226-248. https://doi.org/10.1177/0022002702251031

Canes-Wrone, B., Howell, W. G., \& Lewis, D. E. (2008). Toward a Broader Understanding of Presidential Power: A Reevaluation of the Two Presidencies Thesis. Journal of Politics, 70, 1-16. https://doi.org/10.1017/S0022381607080061

Carey, H. F. (2001). U.S. Domestic Politics and the Emerging Humanitarian Intervention Policy: Haiti, Bosnia, and Kosovo. World Affairs, 164, 72-82.

Choi, S. W. (2013). What Determines US Humanitarian Intervention? Conflict Management and Peace Science, 30, 121-139. https://doi.org/10.1177/0738894212473916

Christenson, D. P., \& Kriner, D. L. (2017). Mobilizing the Public against the President: Congress and the Political Costs of Unilateral Action. American Journal of Political Science, 61, 769-785. https://doi.org/10.1111/ajps.12298

Cohen, J. E. (1991). Historical Reassessment of Wildavsky’s “Two Presidencies” Thesis. Social Science Quarterly, 63, 549-555.

Cooper, P. J. (2014). By Order of the President: The Use and Abuse of Executive Direct Action (2nd ed.). Lawrence, KS: University Press of Kansas.

Copeland, D. C. (2000). The Origins of Major War. Ithaca, NY: Cornell University Press. 
Dahl, R. A. (1971). Polyarchy: Participation and Opposition. New Haven, CT: Yale University Press.

Deering, C. J., \& Maltzman, F. (1999). The Politics of Executive Orders: Legislative Constraints on Presidential Power. Political Research Quarterly, 52, 767-783. https://doi.org/10.1177/106591299905200405

Finnemore, M., \& Sikkink, K. (1998). International Norm Dynamics and Political Change. International Organization, 52, 887-917. https://doi.org/10.1162/002081898550789

Fisher, L. (2004). Presidential War Power (2nd ed.). Lawrence, KS: University Press of Kansas.

Fleisher, R., Bond J. R., Krutz G. S., \& Hanna S. (2000). The Demise of the Two Presidencies. American Politics Research, 28, 3-25. https://doi.org/10.1177/1532673X00028001001

Fordham, B. (1998). Partisanship, Macroeconomic Policy, and U.S. Uses of Force, 1949-1994. Journal of Conflict Resolution, 42, 418-439. https://doi.org/10.1177/0022002798042004002

Gerring, J., Ziblatt, D., Van Gorp, J., \& Arévalo, J. (2011). An Institutional Theory of Direct and Indirect Rules. World Politics, 63, 377-433. https://doi.org/10.1017/S0043887111000104

Gries, P. H. (2014). The Politics of American Foreign Policy: How Ideology Divides Liberals and Conservatives over Foreign Affairs. Palo Alto, CA: Stanford University Press.

Hermann, C. F. (Ed.) (1972). International Crises: Insights from Behavioral Research. New York: Free Press.

Hermann, M. G., \& Kegley, C. W. (1998). The U.S. Use of Military Intervention to Promote Democracy: Evaluating the Record. International Interactions, 24, 91-114. https://doi.org/10.1080/03050629808434922

Holsti, O. R., \& Rosenau, J. N. (1996). Liberal, Populists, Liberatarians, and Conservatives: The Link between Domestic and International Affairs. International Political Science Review, 17, 29-54. https://doi.org/10.1177/019251296017001003

Howell, W. G., \& Lewis, D. E. (2002). Agencies by Presidential Design. Journal of Politics, 64, 1095-1114. https://doi.org/10.1111/1468-2508.00164

Howell, W. G., \& Pevehouse, J. C. (2005). Presidents, Congress, and the Use of Force. International Organization, 59, 209-232. https://doi.org/10.1017/S0020818305050034

Howell, W. G., \& Pevehouse, J. C. (2007a). While Dangers Gather: Congressional Checks on Presidential War Powers. Princeton, NJ: Princeton University Press.

Howell, W. G., \& Pevehouse, J. C. (2007b). When Congress Stops Wars: Partisan Politics and Presidential Power. Foreign Affairs, 86, 95-107.

Huth, P. K. (1998). Major Power Intervention in International Crises, 1918-1988. Journal of Conflict Resolution, 42, 744-770. https://doi.org/10.1177/0022002798042006004

Ingberman, D., \& Villani, J. (1993). An Institutional Theory of Divided Government and Party Polarization. American Journal of Political Science, 37, 429-471. https://doi.org/10.2307/2111380

Irons, P. (2005). War Powers: How the Imperial Presidency Hijacked the Constitution. New York: Metropolitan Books/Henry Holt.

James, P., \& Oneal, J. R. (1991). The Influence of Domestic and International Politics on the President's Use of Force. Journal of Conflict Resolution, 35, 307-332.

https://doi.org/10.1177/0022002791035002008 
Kartzmann, R. (1990). A Question of Balance: The President, the Congress, and Foreign Policy. In T. Mann (Ed.), A Question of Balance: The President, the Congress, and Foreign Policy. Washington DC: Brookings Institution.

Koh, H. H. (1991). The National Security Constitution: Sharing Power after the Iran-Contra Affair. New Haven, CT: Yale University Press.

Krause, G. A., \& Cohen, D. B. (1997). Presidential Use of Executive Orders, 1953-1994. American Politics Research, 25, 458-481. https://doi.org/10.1177/1532673X9702500403

Krause, G. A., \& Cohen, J. E. (2000). Opportunity, Constraints, and the Development of the Institutional Presidency: The Issuance of Executive Orders, 1939-96. Journal of Politics, 62, 88-114. https://doi.org/10.1111/0022-3816.00005

Krehbiel, K. (1998). Pivotal Politics: A Theory of U.S. Lawmaking. Chicago, IL: University of Chicago Press. https://doi.org/10.7208/chicago/9780226452739.001.0001

Kriner, D. L. (2006). Taming the Imperial Presidency: Congress, Presidents, and the Conduct of Military Action. Cambridge, MA: Harvard University Press.

Kriner, D. L. (2010). After the Rubicon: Congress, Presidents, and the Politics of Waging War. Chicago, IL: University of Chicago Press. https://doi.org/10.7208/chicago/9780226453583.001.0001

Lebow, R. N. (1981). Between Peace and War: The Nature of International Crisis. Baltimore, MD: John Hopkins University Press.

Lektzian, D., \& Souva, M. (2007). An Institutional Theory of Sanctions Onset and Success. The Journal of Conflict Resolution, 51, 848-871. https://doi.org/10.1177/0022002707306811

Lian, B., \& Oneal, J. R. (1993). Presidents, the Use of Military Force, and Public Opinion. Journal of Conflict Resolution, 37, 277-300. https://doi.org/10.1177/0022002793037002003

Linder, S. H., \& Peters, B. G. (1990). An Institutional Approach to the Theory of Policy-Making: The Role of Guidance Mechanism in Policy Formulation. Journal of Theoretical Politics, 2, 59-83. https://doi.org/10.1177/0951692890002001003

Lindsay, J. M. (1994). Congress, Foreign Policy, and the New Institutionalism. International Studies Quarterly, 38, 281-304. https://doi.org/10.2307/2600978

Lindsay, J. M., \& Ripley, R. B. (1993). How Congress Influences Foreign and Defense Policy. In R. B. Ripley, \& J. M. Lindsay (Eds.), Congress Resurgent: Foreign and Defense Policy on Capitol Hill (pp. 7-32). Ann Arbor, MI: University of Michigan Press.

Makinda, S. M. (2008). The African Union: Challenges of Globalization, Security, and Governance. New York: Routledge Press.

Marshall, B. W., \& Pacelle, R. L. (2005). Revisiting the Two Presidencies. American Politics Research, 33, 81-105. https://doi.org/10.1177/1532673X04266816

Mastanduno, M. (1997). Preserving the Unipolar Moment: Realist Theories and U.S. Grand Strategy after the Cold War. International Security, 21, 49-88. https://doi.org/10.1162/isec.21.4.49

Mayer, K. R. (1999). Executive Orders and Presidential Power. The Journal of Politics, 61, 445-466. https://doi.org/10.2307/2647511

Mayer, K. R. (2002). With the Stroke of a Pen: Executive Orders and Presidential Power. Princeton, NJ: Princeton University Press.

McCormick, J. M., \& Wittkopf, E. R. (1990). Bipartisanship, Partisanship, and Ideology in Congressional-Executive Foreign Policy Relations, 1947-1988. The Journal of Politics, 52, 1077-1100. https://doi.org/10.2307/2131683 
Mearsheimer, J. J. (2001). The Tragedy of Great Power Politics. New York: W.W. Norton \& Company.

Meernik, J. (1994). Presidential Decision Making and the Political Use of Military Force. International Studies Quarterly, 38, 121-138. https://doi.org/10.2307/2600874

Meernik, J. (2000). Modeling International Crises and the Political Use of military Force by the USA. Journal of Peace Research, 37, 547-562.

https://doi.org/10.1177/0022343300037005001

Milner, H. V., \& Tingley, D. H. (2015). Sailing at the Water's Edge: The Domestic Politics of American Foreign Policy. Princeton, NJ: Princeton University Press. https://doi.org/10.1515/9781400873821

Moe, T. M., \& Howell, W. G. (1999a). The Presidential Power of Unilateral Action. Journal of Law, Economics, and Organization, 15, 132-179.

Moe, T. M., \& Howell, W. G. (1999b). Unilateral Action and Presidential Power: A Theory. Presidential Studies Quarterly, 29, 850-872.

Mueller, J. E. (1973). War, Presidents, and Public Opinion. New York: John Wiley \& Sons.

Narizny, K. (2001). The Political Economy of Grand Strategy. Ithaca, NY: Cornell University Press.

Ornstein, N. J., Mann, T. E., Malbin, M.J., Rugg, A., \& Wakeman, R. (2017). Vital Statistics on Congress. Washington DC.

https://www.brookings.edu/wp-content/uploads/2016/07/Vital-Statistics-Full-Data-Set. pdf

Ostrom, C. W., \& Job, B. L. (1986). The President and the Political Use of Force. The American Political Science Review, 80, 541-566. https://doi.org/10.2307/1958273

Palmer, G., D’Orazio, V., Kenwick, M., \& Lane, M. (2015). The MID4 Data Set: Procedures, Coding Rules, and Description. Conflict Management and Peace Science, 32, 222-242. https://doi.org/10.1177/0738894214559680

Peceny, M. (1995). Two Paths to the Promotion of Democracy during U.S. Military Interventions. International Studies Quarterly, 39, 371-401. https://doi.org/10.2307/2600926

Peters, G., \& Woolley, J. T. (2018). The American Presidency Project. Santa Barbara, CA: University of California Santa Barbara. https://www.presidency.ucsb.edu/

Powell, G. B. (1982). Contemporary Democracies: Participation, Stability, and Violence. Cambridge, MA: Harvard University Press.

Prins, B. C. (1999). The Politics of Conflict Resolution: Evaluating the Determinants of American Third-Party Intervention, 1918-1994. Doctoral Dissertation, East Lansing, MI: Michigan State University.

Rathbun, B. C. (2008). Does One Right Make a Realist? Conservatism, Neoconservatism, and Isolationism in the Foreign Policy Ideology of American Elites. Political Science Quarterly, 123, 271-299. https://doi.org/10.1002/j.1538-165X.2008.tb00625.x

Rothstein, B., \& Stolle, D. (2008). The State and Social Capital: An Institutional Theory of Generalized Trust. Comparative Politics, 40, 441-459. https://doi.org/10.5129/001041508X12911362383354

Ruggie, J. G. (1998). What Makes the World Hang Together? Neo-Utilitarianism and the Social Constructivist Challenge. International Organization, 52, 855-885.

https://doi.org/10.1162/002081898550770

Schraufnagel, S., \& Shellman, S. M. (2001). The Two Presidencies, 1984-98: A Replication 
and Extension. Presidential Studies Quarterly, 31, 699-707.

https://doi.org/10.1111/j.0000-0000.2001.00194.x

Scott, W. R. (2008). Approaching Adulthood: The Maturing of Institutional Theory. Theory and Society, 37, 427-442. https://doi.org/10.1007/s11186-008-9067-z

Scott, W. R. (2014). Institutions and Organizations: Ideas, Interests, and Identities (4th ed.). Thousand Oaks, CA: Sage Publishing.

Sigelman, L. (1979). A Reassessment of the Two Presidencies Thesis. The Journal of Politics, 41, 1195-1205. https://doi.org/10.2307/2129741

Small, M., \& Singer, D. (1990). National Material Capabilities Dataset. Ann Arbor, MI: University of Michigan.

Stimson, J. A. (1999). Public Opinion in America: Moods, Cycles, and Swings (2nd ed.). Boulder, CO: Westview Press.

Tabachnick, B., \& Fidell, L. S. (2015). Using Multivariate Statistics (6th ed.). New York: Pearson Longman.

Tannenwald, N. (1999). The Nuclear Taboo: The United States and the Normative Basis of Nuclear Non-Use. International Organization, 53, 433-468. https://doi.org/10.1162/002081899550959

Waltz, K. N. (1979). Theory of International Politics. New York: Random House.

Weissman, S. R. (2017). Congress and War: How the House and the Senate Can Reclaim Their Role. Foreign Affairs, 96, 132-145.

Wendt, A. (1992). Anarchy Is What States Make of It: The Social Construction of Power Politics. International Organization, 46, 391-425. https://doi.org/10.1017/S0020818300027764

Wiarda, H. J. (2009). Divided America on the World Stage: Broken Government and Foreign Policy. Washington DC: Potomac Books, Inc.

Wildavsky, A. (1966). The Two Presidencies. Trans-Action, 4, 7-14. https://doi.org/10.1007/BF02810961

Wooldridge, J. M. (2013). Introductory Econometrics: A Modern Approach (5th ed.). Boston, MA: South-Western Cengage Learning.

Zaller, J. R. (1992). The Nature and Origins of Mass Opinion. New York: Cambridge University Press. https://doi.org/10.1017/CBO9780511818691 


\section{Appendix}

This appendix will elaborate the factor analysis processes that were used to create the measures of Support for the President and Conservativism in each of the two-chambers of Congress. In addition, we report an abbreviated model that uses each individual crisis as the unit of analysis instead of country/quarter year.

Factor Analyses: Specifics and Diagnostics.

Table A1 (House) and Table A2 (Senate), provide information about the latent measures we used to capture congressional Support for the President and Conservativism. The Factor Analysis models use oblique rotation to simplify the factor structure. Specifically, we use oblique promax rotation because we believe there is a correlation between the two factors we are trying to capture. For example, the level of conservatism increases as legislator support for Republican presidents' increases. Using oblique promax rotation allows us to account for this correlation and prevent any bias the relationship might create for our factor loadings (see Bartolomew, Steele, Moustaki, \& Galbraith, 2008; Tabachnick \& Fidell, 2015). Note in the Tables, Factor 1 finds all three Conservativism measures loading on a single dimension and that Factor 2 finds all three Support for the President considerations loading together. We should point out that in both

Table A1. Factor analysis: The house.

\begin{tabular}{cccc}
\hline Conservativism & Factor 1 & Factor 2 & Uniqueness \\
\hline Chamber Ideology $[\mathrm{t}-1]$ & .969 & -.034 & .057 \\
Avg. Committee Ideology $[\mathrm{t}-1]$ & .932 & .007 & .133 \\
Foreign Affairs Ideology $[\mathrm{t}-1]$ & .972 & .069 & .057 \\
& Support for President & & \\
President's Party (\%) & .033 & .946 & .106 \\
President Party Power [t -1$]$ & .063 & .981 & .039 \\
Presidential Batting Average [t - 1] & -.126 & .751 & .410 \\
\hline
\end{tabular}

Note: The Values are promax-rotated factor loadings. Cronbach's $\alpha=.89$ for Presidential Support and $\alpha$ $=.93$ for Conservativism.

Table A2. Factor analysis: The senate.

\begin{tabular}{cccc}
\hline Conservativism & Factor 1 & Factor 2 & Uniqueness \\
\hline Chamber Ideology $[\mathrm{t}-1]$ & .961 & -.082 & .047 \\
Avg. Committee Ideology $[\mathrm{t}-1]$ & .951 & -.036 & .084 \\
Foreign Relations Ideology $[\mathrm{t}-1]$ & .865 & .068 & .264 \\
Presidential Support & -.124 & .928 & .091 \\
President's Party (\%) & -.053 & .964 & .054 \\
President Party Power $[\mathrm{t}-1]$ & .173 & .809 & .355 \\
\hline
\end{tabular}

Note: The values are promax-rotated factor loadings. Cronbach's $\alpha=.89$ for Presidential Support and .92 for Conservativism. 
Table A3. US Military Intervention (1954-2013): The Role of Legislator Support for the President and Legislative Conservativism (Crisis Level Observations).

\begin{tabular}{|c|c|c|c|}
\hline & Exp. & House Model & Senate Model \\
\hline Key Explanatory Variables & Sign & Coefficient (s.e.) & Coefficient (s.e.) \\
\hline Support for the President (House) & + & $.842(.367)^{\star}$ & \\
\hline Support for the President (Senate) & + & & $.976(.319)^{\star \star}$ \\
\hline Conservativism (House) & + & $1.920(.706)^{\star \star}$ & \\
\hline Conservativism (Senate) & + & & $.883(.425)^{*}$ \\
\hline \multicolumn{4}{|c|}{ With Controls and Presidential Fixed Effects } \\
\hline Constant & & $-7.014(1.728)^{\star \star}$ & $-5.475(1.757)^{\star *}$ \\
\hline McFadden Pseudo $\mathrm{R}^{2}$ & & .432 & .427 \\
\hline Deviance & & 79.84 & 80.55 \\
\hline AIC & & 123.84 & 124.55 \\
\hline $\mathrm{BIC}$ & & 199.48 & 200.19 \\
\hline $\mathrm{n}$ & & 230 & 230 \\
\hline
\end{tabular}

Robust standard errors clustered by Congress. ${ }^{*} p<.05 ;{ }^{* *} p<.01$ (two-tailed test).

Tables there is one variable with a somewhat large uniqueness score. Presidential Batting Average in both the House and Senate analyses is somewhat distinct from other considerations. However, the Cronbach Alpha scores reported in the table footnotes suggest adequate model fit. Both House and Senate examinations produce a Cronbach's Alpha score greater than .89 and, we hold, the factors can usefully represent the latent measures of Support for the President and Conservativism.

\section{Using a Different Unit of Analysis.}

As noted in Footnote 7 we also test our institutional thesis using each foreign policy crisis as the unit of analysis as opposed to crisis actors. The results of this analysis are reported in Table A3. We learn that support for the president in each chamber and chamber conservativism are each statistically linked in the hypothesized correct direction in the same manner as results reported in the text. Beyond the results (reported in Table A3) we also perform several other robustness tests whereby we add variables to the model that control for whether the crisis was occurring in the Middle East and/or Central America, representing regions of strategic interest to the US. In addition, we check our results by controlling for the geographic proximity of the crisis to the US (crisis occurring in North, Central and South America). Finally, we create a model that uses a proxy for geostrategic salience. The alternative measure is a simple binary consideration that taps whether the Soviet Union or Russia was a third-party intervener in the crisis. None of these model alternatives influence our key findings. The results of the alternative model runs are available from the authors upon request. 